\title{
Pengaruh Stimulus Orang Tua Terhadap Perkembangan Prestasi Anak Sekolah Dasar
}

\author{
Serlina Agustin ${ }^{1}$, Triana Lestari ${ }^{2}$, \\ 1 Pendidikan Guru Sekolah Dasar, Universitas Pendidikan Indonesia Kampus Daerah Cibiru \\ ${ }^{2}$ Pendidikan Guru Sekolah Dasar, Universitas Pendidikan Indonesia Kampus Daerah Cibiru \\ * Corresponding Author. E-mail: ${ }^{1}$ serlina@upi.edu
}

Receive: $27 / 06 / 2021$

Accepted:25/08/2021

Published: 01/10/2021

\begin{abstract}
Abstrak
Penelitian ini bertujuan untuk mengetahui bagaimana bentuk stimulus orang tua terhadap anak Sekolah Dasar dan mengetahui bagaimana pengaruh stimulus orang tua terhadap perkembangan prestasi anak Sekolah Dasar. Metode penelitian yang digunakan yaitu metode observasi dan studi kasus dengan pendekatan kualitatif. Informan penelitian yaitu orang tua yang memiliki anak yang duduk di bangku Sekolah Dasar, dengan teknik pengumpulan data yaitu dengan cara asynchronus menggunakan media google formulir. Hasil penelitian menunjukkan bahwa orang tua yang memiliki anak Sekolah Dasar selalu memberi stimulus untuk memperoleh prestasi. Bentuk stimulus yang diberikan yakni dorongan kepada anak supaya dapat belajar giat mewujudkan cita-citanya, dukungan (support), memfasilitasi penunjang prestasi, memberikan motivasi, orang tua juga selalu mengarahkan hal-hal yang positif kepada anak. Stimulus juga memiliki pengaruh positif dan negatif terhadap perkembangan prestasi. Pengaruh positif dari pemberian stimulus orang tua terhadap perkembangan prestasi anak yaitu mempermudah mengembangkan karakter anak, meningkatkan kepercayaan diri, menggali potensi terpendam pada anak, memotivasi anak untuk terus belajar. Pemberian stimulus orang tua juga memiliki pengarh negative, salah satunya dengan aadanya stimulus terus menerus dari orang tua yaitu anak menjadi terus menerus ingin didorong oleh orang tua tanpa ada kesadaran dari diri sendiri.
\end{abstract}

Kata Kunci: Stimulus, Orang Tua, Perkembangan Prestasi, Anak Sekolah Dasar

The Influence Of Parental Stimulus On Achievement Development Of Elementary School Children

\begin{abstract}
This research aims to determine how the form of parental stimulus towards elementary school children and to find out how the influence of parental stimuli on the development of achievement of elementary school children. The research method used is the method of observation and case studies with a qualitative approach. Research informants are parents who have children who are in elementary school, with data collection techniques, namely asynchronously using google form media. The results showed that parents who have elementary school children always provide a stimulus for achievement. The form of stimulus provided is encouragement to children so they can study hard to realize their goals, support, facilitate achievement support, provide motivation, parents also always direct positive things to children. Stimulus also has a positive and negative influence on achievement development. The positive effect of giving parental stimuli on the development of children's achievement is making it easier to develop children's character, increasing self-confidence, exploring hidden potential in children, motivating children to continue learning. The provision of parental stimuli also has negative effects, one of which is the continuous stimulus from the parents, namely the child continues to want to be pushed by the parents without any awareness of themselves.
\end{abstract}

Keywords: Stimulus, Parents, Achievement Development, Elementary School Children 


\section{Pendahuluan}

Sejatinya, anak usia Sekolah Dasar memiliki kemampuan dan karakter masingmasing dalam perkembangan prestasinya. Sekolah Dasar dapat menjadi pintu utama anak dalam mengembangkan potensinya sebagai bentuk persiapan melanjutkan ke jenjang selanjutnya yang lebih tinggi. Sekolah Dasar memiliki pengaruh yang besar terhadap keberhasilan belajar anak, karena berhasil atau tidaknya anak di Sekolah Dasar akan menentukan berhasil atau tidaknya anak di pendidikan selanjutnya.

Teori Perkembangan Kognitif oleh Jean Piaget menyebutkan, bahwa anak usia Sekolah Dasar dimulai dari usia tujuh tahun, dan pada masa ini anak sedang di tahap operasional konkret (Santrock, 2014., Ghazi dan Ullah, 2015). Tahap operasional konkret dimulai saat usia tujuh tahun sampai sebelas tahun (Aisyah, S. 2013) dan dalam tahap ini memperlihatkan perkembangan yang pesat dalam aspek kognitif pada anak, khususnya yang berhubungan dengan penalaran logika. Maka dari itu, sangat diperlukan adanya pengembangan aspek kognitif anak di sekolah dasar untuk meningkatkan prestasi belajar anak tentunya tidak hanya prestasi akademik saja yang terbilang sebagai prestasi belajar, tetapi juga prestasi non akademik (melalui minat dan bakat).

Prestasi anak tercipta saat anak mampu mengembangkan karakter dan bakat serta minatnya secara alami maupun dengan dorongan. Menurut Muhammad Ilyas Ismail, 2020 (dalam Samrin 2016:122) pendidikan nasional menjadikan pendidikan karakter sebagai salah satu bagian penting dalam tujuan pendidikan. Sebuah karakter menjadi hal penting dalam mengembangkan prestasi anak. Karena dalam karakter terdapat hal yang mewadahi anak untuk mengembangkan minat dan bakatnya. Anak yang memiliki karakter kuat, sangat mudah menerima sesuatu dalam dunia mereka. Sehingga, anak tersebut merasakan kesenangan tersendiri dengan terus menerus mengembangkan prestasinya. Karakter sangat penting untuk dimiliki seorang anak, terutama dalam pengembangan prestasi.

Prestasi anak memiliki banyak bentuk, baik berupa prestasi belajar (akademik) maupun prestasi minat dan bakat (non akademik). Prestasi belajar (akademik) yakni suatu pengetahuan atau keterampilan yang ingin dicapai serta dikembangkan melalui mata pelajaran di sekolah dan nilai ujian atau nilai yang diberikan guru sebagai penentu prestasi belajar tersebut. (Goods dalam Annes, 2013). Prestasi belajar biasanya dilihat dalam penilaian akhir semester di Sekolah Dasar. Hasil anak selama melakukan pembelajaran di sekolah di akumulasikan dalam sebuah hasil laporan (Rapor). Anak yang memiliki prestasi lebih unggul biasanya menduduki rangking tertinggi, begitupun seterusnya sesuai dengan nilai yang didapat.

Menurut Darmadi (dalam Siti, 2015:30) prestasi belajar memiliki dua faktor yang dapat memberi pengaruh, yaitu faktor eksternal (luar) dan faktor internal (dalam). Faktor eksternal (luar) meliputi sosial dan non-sosial, sedangkan faktor internal (dalam) meliputi sikap dan motivasi serta minat dan intelegensi. Faktor eksternal berupa sosial dan non sosial dilihat dari aktivitas anak, apakah anak tersebut mampu mengembangkan prestasinya bersama orang di sekitarnya yakni melakukan kegiatan sosial (bersosialisasi) atau bahkan anak mampu mengembangkan prestasinya secara mandiri tanpa adanya kegiatan sosial atau aktivitas sosial yang mendukung (non sosial).

Faktor internal (dalam) berupa sikap dan motivasi serta minat dan intelegensi, dapat dilihat dari individu anak menyikapi hal-hal atau kemampuan yang ada pada diri anak tersebut. Anak yakni mampu menyesuaikan sikap yang berkembang di 
individu mereka sehingga menciptakan minat yang menjadi faktor pendorong dalam perkembangan prestasi anak. Dengan begitu, anak akan mampu mengembangkan minat dan potensinya dengan penuh motivasi dari diri sendiri. Karena telah lahir sikap percaya diri akan kemampuan yang dimiliki anak.

Kemudian, prestasi anak berupa prestasi non akademik, menurut Handayani, L. (2010). Prestasi non akademik yaitu prestasi siswa yang dicapai melalui kegiatan di luar pembelajaran (kegiatan ekstrakurikuler) di sekolah. Prestasi non akademik sangat beragam, karena merupakan lahir dari minat dan bakat anak. Biasanya prestasi non akademik ini dapat menjadi penunjang anak dalam mewadahi hobi. Bentuk prestasi non akademik misalnya dalam bidang seni, olahraga, dan public spreaking (bahasa).

Di Sekolah Dasar, biasanya anak diperkenalkan pembelajaran nonakademik melalui kegiatan ekstrakulikuler. Karena, sistem pendidikan juga memiliki kegiatan rutin setiap tahun di jenjang SD, SMP, dan SMA seperti adanya kegiatan FLS2N dan O2SN. Khusus untuk anak di Sekolah dasar, biasanya anak dibimbing oleh guru untuk mengikuti kegiatan tersebut. Anak yang memiliki kemuan atau bakat di bidang menggambar, menulis (seperti menulis puisi dan cerpen), menyanyi, menari, dan olahraga akan diajak untuk mengikuti kegiata tersebut. Kegiatan ini bisa dikatakan sebagai pengembangan potensi-potensi yang dimiliki oleh anak di Sekolah Dasar. Supaya, anak memiliki bekal pengalaman yang luar biasa ketika melanjutkan ke jenjang pendidikan selanjutnya. Itu semua bisa dikatakan sebagai prestasi yang biasanya banyak dimiliki oleh anak Sekolah Dasar.

Prestasi anak dapat dilihat dari berbagai perkembangan diri seorang anak. Apabila anak mampu mengekpresikan diri melalui sebuah tulisan, maka berikan stimulus yang tepat dalam perkembangan anak itu, supaya anak dapat mengembangkan bakatnya untuk meraih prestasi yang diinginkan atau sesuai dengan minat dan bakatnya. Jika anak mendapat stimulus yang tidak sesuai dengan keinginan (minat dan bakatnya), maka stimulus tersebut belum bisa dikatakan berhasil karena ada ketidaksiapan dari individu setiap anak.

Dalam Handout PSY (2016), stimulus merupakan segala kejadian dan pengaruh dari dalam maupun luar yang dapat memberikan rangsangan kepada reseptor sensoris, sehingga dapat menciptakan suatu respon pada individu. Dalam hal ini, selain guru yang membimbing anak belajar di Sekolah Dasar, tetapi orang tua juga sangat penting untuk memberikan stimulus kepada anak di jenjang Sekolah Dasar. Karena anak di usia Sekolah Dasar itu masih memiliki kepribadian yang labil, maka perlu adanya pengawasan di lingkungan sekolah ataupun di lingkungan keluarga.

Menurut Abdul Alim, 2009 (dalam Moch. Fahmi, dkk., 2020: 20) anak Sekolah Dasar memiliki karakteristik dilihat dari fisiknya. Pertama, anak usia Sekolah Dasar itu senang bermain. Maka, orang tua bisa memberikan stimulus tanpa adanya larangan anak untuk bermain. Orang tua bisa menjadikan permainan sebagai pendorong anak untuk semangat belajar, yakni menanambah kegiatan bermain sambil belajar. Kedua, anak usia Sekolah Dasar senang bergerak, berbeda dengan orang dewasa yang bisa duduk selama berjam-jam. Maka, orang tua harus mendukung anaknya aktif baik itu di lingkungan keluarga ataupun lingkungan masyarakat. Hal ini bisa menambah rasa percaya diri anak dan menciptakan jiwa semangat dalam mengembangan potensinya. Ketiga, anak usia Sekolah Dasar senang berkegiatan kelompok, terutama dengan teman sebaya nya. Maka, orang tua dalam memberikan stimulus kepada anak 
harus memiliki strategi tanpa melarang anak untuk bermain. Karena, terkadang ada orang tua yang mengharuskan anaknya untuk mengembangkan potensinya, misalkan di bidang seni vokal. Anaknya dituntut untuk terus berlatih vocal tanpa ada waktu bermain dengan teman sebaya nya. Nah, hal ini sangat tidak dianjurkan. Karena aktivitas bermain dengan teman-teman sebaya itu memiliki pengaruh baik terhadap pribadi anak. Dengan bermain berkelompok, akan tumbuh pribadi anak yang senang tolong menolong dengan temannya, saling membantu bahkan jiwa sosialnya tertanam dengan baik.

Menurut Putra, A.Y. dkk. (2018), proses perkembangan anak dapat berlangsung secara alamiah, akan tetapi keberlangsungan proses tersebut bergantung dan sangat dipengaruhi oleh keberadaan orang dewasa atau orang tua. Di lingkungan keluarga tentunya, orang tua sangat berperan memberi stimulus kepada anak. Karena stimulus yang diberikan orang tua sangat mempengaruhi perkembangan prestasi anak. Banyak orang tua yang memiliki keinginan yang besar untuk anaknya dapat memiliki prestasi yang membanggakan, tidak sedikit pula orang tua yang tidak mendukung anaknya untuk menoleh prestasi, dalam hal lain tidak memberikan stimulus (dorongan) kepada anak. Semua itu terjadi karena orang tua juga memiliki prinsip tersendiri dalam membimbing anaknya untuk memperoleh prestasi. Namun, orang tua adalah guru anak yang utama. Sebagai orang terpenting di kehidupan anak, orang tua sudah seharusnya memberikan stimulus penuh untuk anaknya. Karena, sikap anak terlahir dari didikan orang tua sebagai orang yang membesarkannya.

Perlu kita ketahui, bahwa saat ini stimulus sangat perlu ditingkatkan oleh orang tua, terlebih di zaman sekarang dengan adanya pandemi Covid-19 yang sedang mewabah dan sistem pendidikan menjadi terpengaruh oleh pandemi Covid19 ini. Anak Sekolah Dasar melakukan pembelajaran jarak jauh (PJJ) yakni melakukan pembelajaran di rumah bukan di sekolah. Bentuk pembelajarannya pun berbeda, anak belajar secara mandiri di rumah tanpa bertemu dan berkumpul serta belajar bersama dengan teman-temannya. Hal ini tentunya menjadi tantangan orang tua untuk dapat mengawasi anaknya dalam proses belajar. Karena, pembelajaran jarak jauh banyak memberi pengaruh yang beragam, baik itu pengaruh positif atau pengaruh negatif terhadap perkembangan prestasi anak. Maka dari itu, untuk menstabilkan perkembangan anak dalam prestasinya, orang tua memiliki berbagai langkah dalam menstimulasi anaknya. Pemberian stimulus anak oleh orang tua tentunya sangat beragam sesuai dengan kemampuan orang tua dan kesanggupan anak menerima stimulus dari orang tuanya.

Dari hal tersebut, maka penulis menentukan rumusan masalah untuk diteliti yaitu bagaimana bentuk stimulus yang diberikan orang tua kepada anak Sekolah Dasar serta bagaimana pengaruh stimulus orang tua terhadap perkembangan prestasi anak Sekolah Dasar. Serta dari rumusan masalah yang ditentukan, tujuan dari penelitian ini yakni untuk mengetahui bentuk stimulus orang tua terhadap anak Sekolah Dasar dan mengetahui pengaruh stimulus orang tua terhadap perkembangan prestasi anak Sekolah Dasar.

\section{Metode}

Metode yang digunakan dalam penelitian ini yaitu observasi dan studi kasus, dengan menggunakan pendekatan kualitatif, untuk mengetahui bagaimana bentuk stimulus orang tua terhadap anak Sekolah Dasar dan mengetahui bagaimana pengaruh stimulus orang tua terhadap perkembangan prestasi anak Sekolah Dasar. Pendekatan kualitatif bertujuan menjabarkan fenomena dan disajikan sesuai 
fakta di lapangan (David, 2016:10). Penelian ini melibatkan orang tua yang memiliki anak yang duduk di bangku Sekolah Dasar sebagai informan dan mengambil 7 data dari hasil pengumpulan data yang diperoleh.

Teknik pengumpulan data yang digunakan dalam penelitian ini yakni asynchronus dengan menggunakan media google formulir. Peneliti mengumpulkan data yang diperoleh dari responden, kemudian hasil pengumpulan data yang diperoleh dianalisis dengan menggunakan teknik analisis data kualitatif. Aktifitas dalam analisis data, yaitu dengan teknik reduction. Reduction adalah kegiatan mereduksi data hasil penelitian dengan membuat rangkuman, memilih hal-hal yang pokok dan memfokuskan pada hal-hal yang sesuai di lapangan. (Ahmad Rijali 2018:91). Dengan demikian, data yang telah direduksikan akan memberikan gambaran yang dapat mempermudah peneliti untuk mendapatkan hasil analisis data. Hasil dari analisis data kemudian disimpulkan dengan menggunakan metode conclusion, yakni menyajikannya dalam bentuk uraian serta disimpulkan sesuai dengan data hasil yang didapat dari responden.

\section{Hasil dan Pembahasan}

Berdasarkan data hasil penelitian, peneliti mendapatkan para orang tua yang memiliki anak yang duduk di bangku Sekolah Dasar selalu memberi stimulus kepada anaknya untuk memperoleh prestasi. Karena, orang tua merasa sangat bangga apabila memiliki anak yang banyak meraih prestasi, baik prestasi akademik maupun non akademik. Dari data hasil penelitian, bentuk stimulus yang diberikan oleh orang tua kepada anak yang duduk di bangku Sekolah Dasar berbeda-beda. Para orang tua memiliki berbagai macam bentuk stimulus sebagai bentuk pendekatan dan dorongan kepada anaknya yang tentunya disesuaikan dengan kondisi setiap anak. Karena diri seorang anak itu memiliki perbedaan di setiap individunya, dan orang tua yang mengetahui bagaimana karakter anaknya sendiri. Maka dari itu, orang tua harus mengerti bagaimana pemberian stimulus yang tepat untuk anaknya tanpa menimbulkan hal yang dapat merusak diri maupun mental pribadi anak.

Adapun bentuk stimulus yang digunakan yakni dorongan kepada anak supaya dapat bekerja keras mewujudkan cita-citanya dengan cara belajar dengan sungguh-sungguh. Menurut hasil penelitian, orang tua memberi dorongan kepada anak untuk selalu berlajar dengan sungguhsungguh karena menurutnya pendidikan itu sangat penting untuk masa depan. Jika di lingkungan keluarga anak kurang memiliki pengetahuan dengan maksimal atau bahkan pendidikannya terbatas, maka melalui pendidikan di sekolah orang tua bisa lebih memperlihatkan kemampuan anaknya dengan berinteraksi di lingkungan sekolah dan diberikan ilmu pembelajaran lain oleh guru.

Selain itu, dukungan (support) juga diberikan oleh orang tua yaitu dengan selalu mendukung hal-hal atau aktivitas yang disukai oleh anak. Seperti, dalam hal bakat anak. Orang tua biasanya mengetahui segala aktivitas anaknya. Biasanya, minat dan bakat anak muncul dalam aktivitasnya. Orang tua menjadi lebih peka terhadap anaknya, hal ini dapat menjadi faktor pendorong anak dalam mweujudkan bakatnya. Karena, dengan orang tua melihat dan mengetahui minat dan bakat anak, maka orang tua harus memberi dukungan terhadap minat dan bakat anak. Sebelum memberikan dukungan, tentunya orang tua mempertimbangkan dan melihat bagaimana potensi minat dan bakat anaknya, apakah condong ke arah positif bagi anak atau bahkan condong ke arah negative bagi anak. Jadi, dalam hal ini, orang tua membatasi dukungan kepada hal-hal yang bersifat negatif untuk anaknya. Apabila hal-hal yang disukai oleh anak tersebut bersimpangan, 
maka orang tua memberi pemahaman kepada anak tentunya dengan cara halus, agar anak perlahan mau meninggalkan halhal tersebut dan kembali ke hal-hal yang bersifat positif.

Kemudian, bentuk lainnya yakni orang tua memberi fasilitas untuk menunjang anaknya dalam berproses meraih prestasi dan juga tidak lupa orang tua selalu memberikan motivasi kepada anak dalam mengembangkan prestasinya. Motivasi sangat penting dalam perkembangan prestasi, karena dengan adanya motivasi dari luar, maka anak akan merasakan bagaimana pentingnya menumbuhkan semangat dalam diri anak. Dengan begitu, anak akan merasa bahwa ia bisa mewujudkan prestasinya melalui semangat dari motivasi-motivasi yang didapat.

Dengan adanya fasilitas yang dapat mendorong anak mewujudkan prestasinya, orang tua juga selalu mengarahkan hal-hal yang positif kepada anak sebagai bentuk pengawasan pada perkembangan prestasi anak. Namun, dalam hal ini fasilitas yang diberikan orang tua harus sesuai dengan kebutuhan anak. Dari hasil penelitian, orang tua memberikan fasilitas secara tidak berlebihan, namun disesuaikan dengan apa yang dibutuhkan anak. Karena apabila fasilitas tersebut berlebihan diberikan kepada anak, maka akan ditakutkan anak menjadi haus akan fasilitas orang tuanya. Hal tersebut dapat memicu menurunnya kesadaran anak dalam mengembangkan prestasinya secara mandiri.

Berdasarkan data hasil penelitian, stimulus orang tua memiliki pengaruh besar terhadap kehidupan anak di jenjang selanjutnya. Orang tua selalu ingin memberikan hal yang terbaik untuk anaknya, terlebih saat masih duduk di bangku Sekolah Dasar. Orang tua juga merasakan berbagai respon anak saat diberikan stimulus oleh orang tua. Karena tidak semua anak mampu menerima stimulus dari orang tuanya. Tidak sedikit anak yang awalnya merasa terpaksa untuk mengembangkan prestasinya. Anak merasa tertekan, malas dan tidak bebas. Namun, tidak sedikit pula anak yang semangat menerima stimulus dari orang tuanya, terutama dalam hal pengembangan prestasi. Namun, dilihat dari hasil penelitian, orang tua selalu memberi pengawasan dalam memberikan stimulus kepada setiap anak, agar anak merasa nyaman dengan bentuk stimulus yang diberikan oleh orang tua. Jadi, tidak ada keterpaksaan dalam diri seorang anak menerima stimulus dari orang tuanya, karena orang tua memberikan stimulus yang sesuai dengan karakter individu masing-masing anak.

Dari hasil penelitian yang diperoleh, para orang tua tidak pernah memaksakan dorongannya kepada anak, karena dapat menyebabkan anak menjadi tertekan bahkan stres karena merasa terpaksa melakukan hal yang tidak ia inginkan. Orang tua sendiri memberikan stimulus kepada anak supaya anak memiliki kemauan untuk meningkatkan minat dan bakatnya, yang nantinya anak memiliki bekal untuk masa depannya. Bekal tersebut berupa karakter dari individu anak, pengalaman anak tentunya dengan minat dan bakat yang dimiliki, terciptanya sikap mandiri dalam meraih prestasi, kesiapan mental anak menghadapi dunia luar (bersosialisasi), serta bekal berupa minat dan bakat yang dimiliki.

Dengan adanya dorongan dari orang tua, anak juga memiliki semangat yang tinggi baik itu semangat dalam belajar (akademik) maupun semangat dalam mengembangkan bakat (non akademik). Karena, di kemudian hari anak akan merasakan bagaimana pentingnya semangat yang tinggi dan merasakan bagaimana hasil dari mengembangkan prestasi sejak dini. Prestasi sejak dini menciptakan hal yang baru dalam diri seorang anak. Anak Sekolah Dasar sangat memerlukan stimulus atau dorongan dari orang dewasa, maka dari data hasil 
penelitian para orang tua selalu memberi motivasi dan support untuk anaknya bisa memiliki semangat yang tinggi dalam mengembangkan potensinya (prestasi).

Berdasarkan hasil penelitian kepada orang tua yang memberikan stimulus kepada anak usia Sekolah Dasar. Stimulus dari orang tua tersebut memiliki pengaruh positif dan pengaruh negatif. Pengaruh positif dari pemberian stimulus orang tua terhadap perkembangan prestasi anak yaitu mempermudah mengembangkan karakter anak. Karena dengan adanya stimulus maka akan menciptakan pula jiwa semangat pada anak, yang nantinya anak akan memiliki kepercayaan diri yang tinggi terhadap kemampuan yang ia miliki. Hal ini, menjadi faktor pendukung dalam menghilangkan jiwa malas atau rasa malu dari diri seorang anak. Karena, terkadang anak memiliki rasa malu untuk mengembangkan bakatnya, namun dengan adanya dorongan dari orang tua maka anak sedikit demi sedikit akan perlahan menggali potensi yang terpendam pada diri seorang anak. Anak akan mengetahui dan menyadari bakat atau kemampuan dirinya, sehingga selalu termotivasi untuk terus belajar. Setelah anak sudah memiliki kemauan dan motivasi tinggi, maka anak akan mandiri dan bersungguh-sungguh mengembangkan atau meraih prestasi yang diinginkan dan yang menjadi tujuan dalam mengembangkan prestasinya.

Dari hasil penelitian, orang tua juga menyebutkan bahwa ada pengaruh negatif dari pemberian stimulus orang tua. Namun disebutkan bahwa dampak negatif tersebut tidak terlalu banyak, karena dalam hal ini berkaitan dengan sikap antara orang tua dan anaknya. Dengan adanya stimulus terus menerus dari orang tua, anak menjadi haus akan stimulus orang tua. Terkadang anak terus menerus ingin didorong oleh orang tua. Ini merupakan hal serius yang perlu diperhatikan. Karena, dapat membuat anak berhenti mengembangkan prestasinya apabila bentuk dorongan tersebut tidak ada.

\section{Simpulan}

Prestasi anak tercipta saat anak mampu mengembangkan karakter dan bakat serta minatnya secara alami maupun dengan adanya stimulus (dorongan). Stimulus orang tua memiliki pengaruh besar terhadap kehidupan anak di jenjang selanjutnya. Bentuk stimulus yang diberikan yakni dorongan kepada anak supaya dapat belajar giat mewujudkan cita-citanya, dukungan (support), memfasilitasi penunjang prestasi, memberikan motivasi, orang tua juga selalu mengarahkan hal-hal yang positif kepada anak.

Pengaruh positif dari pemberian stimulus orang tua terhadap perkembangan prestasi anak yaitu mempermudah mengembangkan karakter anak, meningkatkan kepercayaan diri, menggali potensi terpendam pada anak, memotivasi anak untuk terus belajar. Pemberian stimulus orang tua juga memiliki pengaruh negatif, salah satunya dengan aadanya stimulus terus menerus dari orang tua maka anak akan selalu ingin didorong oleh orang tua tanpa ada kesadaran dari diri sendiri. Maka dari itu, orang tua perlu memberikan stimulus kepada anaknya, namun dengan porsi yang tepat dan sesuai. Orang tua harus paham dan mengerti karakter anak masingmasing. Sehingga memudahkan orang tua untuk dapat memilah stimulus seperti apa yang akan diberikan kepada anaknya.

\section{Daftar Pustaka}

Abdul Alim. 2009. Permainan Mini Tenis Untuk Pembelajaran Pendidikan Jasmani Olahraga Dan Kesehatan Siswa Di Sekolah Dasar. JPJI. Vol 6. No. 2. Nov 2009.

Ahmad Rijali. 2018. Analisis Data Kualitatif. http://jurnal.uinantasari.ac.id/index.php/alhad 
harah/article/viewFile/2374/1 691. Diakses 27 April 2021.

Aisyah, S. 2013. Teori Perkembangan Kognitif Jean Piaget. Jurnal Al Ta'dib.

Https://Media.Neliti.Com/Me dia/Publications/235758-

Teori-Perkembangan-KognitifJean-Piaget-48cba26e.Pdf. Diakses 09 Mei 2021.

Darmadi.2010. Belajar dan Pembelajaran. Jakarta: Bumi Aksara.

David dkk. 2016. Metode Penelitian Kualitatif.

https://simdos.unud.ac.id/upl oads/file pendidikan $1 \mathrm{dir} / 8$ 70ba33936829bb37ecd8f62f8 514ba7.pdf. Diakses $07 \mathrm{Mei}$ 2021.

Ghazi, S. R., dan Ullah, K. 2015. Concrete operational stage of Piaget's cognitive development theory: An implication in learning general science. Gomal University Journal of Research. 31(1), 78- 89.

Handayani, L. 2010. Perbedaan Prestasi Akademik dan Non-Akademik Siswa Kelas XI Program Reguler dan AKselerasi di SMA Negeri 4 Malang. SKRIPSI Jurusan Administrasi Pendidikan - Fakultas IImu Pendidikan UM.

Handout PSY. 2016. Konsep-Konsep Umum Matriks Sejarah Aliran Psikologi. http://www.ocw.upj.ac.id/file
s/Handout-PSY-101-KonsepKonsep-Umum-Matriks-

Sejarah-Aliran-Psikologi2016.pdf. Diakses 08 Mei 2021.

Ismail, Muhammad Ilyas. 2012. Pendidikan Karakter: Suatu Pendekatan Nilai. Makassar, Alauddin University Press.

Moch. Fahmi, dkk. 2020. Pengantar Pendidikan dan Pembelajaran Sekolah Dasar. Tasikmalaya : Edu Publisher.

Putra, A.Y. dkk. 2018. Pengaruh Pemberian Stimulasi Oleh Orang Tua Terhadap Perkembangan Bahasa Pada Anak Usia Toddler Di Paud Asparaga Malang. Jurnal Nursing News.

Samrin. 2016. Pendidikan Karakter (Sebuah Pendekatan Nilai). Jurnal AlTa'dib.

https://media.neliti.com/medi a/publications/235693pendidikan-karakter-sebuahpendekatan-ni-71618df5.pdf. Diakses 09 mei 2021.

Santrock. 2014. Child Development (14th Ed.). New York: McGraw-Hill Publishing.

Siti. 2015. Pengaruh Disiplin Belajar Terhadap Prestasi Belajar Siswa Kelas Iv Sekolah Dasar Negeri Se-Daerah Binaan li Kecamatan Petanahan Kabupaten Kebumen. Jurnal Skripsi. Universitas Negeri Semarang. 